\title{
Penerapan Five Porter Analysis pada Efektifitas Kelangsungan Usaha Pelaku UKM (Studi Kasus UD Rey Collection)
}

\author{
Felicia Fiorenita $^{1}$, Agustine Dwianika ${ }^{2}$ \\ ${ }^{1,2}$ Program Studi Akuntansi \\ ${ }^{1,2}$ Universitas Pembangunan Jaya, Tangerang Selatan, Banten \\ Email : felicia.fiorenita@student.upj.ac.id ${ }^{1}$, agustine.dwianika@upj.ac.id ${ }^{2}$
}

\begin{abstract}
ABSTRAK
UKM menjadi kegiatan usaha yang dapat meningkatkan perekonomian negara. Sudah banyak masyarakat yang mulai beralih menjadi pelaku UKM untuk mendapatkan profit yang lebih besar. Semakin banyak UKM yang dibuat, maka semakin berat persaingan di antara mereka. Untuk membuat usaha menjadi lebih unggul dari pesaing, pelaku usaha membutuhkan strategi yang baik dan tepat. Salah satu strategi yang dapat dengan mudah mengetahui keefektifan kelangsungan usaha dengan menggunakan Five Porter Analysis. Tujuan dibuatnya penulisan ini adalah mengetahui besarnya ukuran keefektifan kelangsungan usaha pelaku UKM serta strategi usaha yang dapat diterapkan untuk memperkuat jangka berjalannya usaha. Metode yang digunakan dalam penulisan ini adalah wawancara dan studi literatur. Wawancara dilakukan untuk mengetahui permasalahan riil yang dihadapi salah satu pelaku UKM yang bersangkutan. Pengambilan data menggunakan studi literatur yaitu dengan mengambil data pustaka, mencatat lalu mengolah bahan data tersebut menjadi sebuah informasi. Manfaat dari penulisan ini adalah para pelaku UKM dapat menfaatkan Five Porter Analysis untuk mengetahui seberapa besar keefektifan usaha yang dijalan dan dapat menemukan solusi untuk meningkatkan berjalannya usaha kedepannya. Hasil penelitian ini adalah Five Porters Analysis dapat dengan mudah menemukan permasalahan dalam kelangsungan usaha dan dapat menentukan stratgi yang dapat dilakukan untuk mencapai keefektifan kelangsungan usaha. Saran untuk penelitian selanjutnya diharapkan mampu mendapatkan informasi yang kuat agar para pembaca dapat memahami penggunaan Five Porter Analysis lebih dalam dan lebih baik.
\end{abstract}

Kata Kunci : Akuntansi, Five Porter Analysis, UKM

\section{ABSTRACT}

SME is a business activity that can improve the country's economy. There have been many people who have started to turn to SMEs to get a bigger profit. The more SMEs that are made, the heavier the competition between them. To make a business superior to competitors, business actors need a good and appropriate strategy. One strategy that can easily determine the effectiveness of business continuity is using the Five Porter Analysis. The purpose of this writing is to determine the size of the measure of the effectiveness of the business continuity of SMEs as well as business strategies that can be applied to strengthen the business run. The methods used in this writing are interviews and literature studies. Interviews were conducted to find out the real problems faced by one of the SME actors concerned. Retrieval of data using literature studies, namely by taking library data, taking notes and then processing the data material into information. The benefit of this writing is that UKM players can take advantage of the 
Five Porter Analysis to find out how much the effectiveness of the business being carried out and can find solutions to improve the running of the business going forward. The result of this research is that Five Porters Analysis can easily find problems in business continuity and can determine strategies that can be done to achieve business continuity effectiveness. Suggestions for further research are expected to be able to get strong information so that readers can understand the use of the Five Porter Analysis more deeply and better.

Keywords : Accounting, Five Porter Analysis, SME

\section{PENDAHULUAN}

UKM (Usaha Kecil Menengah) merupakan salah satu penggerak ekonomi negara. Seiring berkembangnya jaman, banyak para pelaku UKM yang menggunakan teknologi modern untuk menjalankan bisnis mereka. Selain itu, banyak orang memutuskan untuk memulai bisnis sendiri agar mendapatkan keuntungan yang lebih besar. Semakin banyak usaha yang dibuat, maka perkenomian negara semakin meningkat. Perekonomian negate semakin meningkat berkat adanya peningkatkan PDB (Produk Domestik Bruto) secara signifikan setiap tahunnya. Menurut Raselawati (2011), factor pertumbuhan PDB di Indonesia yang dilakukan UKM adalah tenaga kerja UKM, ekspor UKM, jumlah unit UKM dan investasi.

Keuangan menjadi sumber informasi keputusan pengusaha apakah usaha yang dijalankan bisa melanjutkan usahanya atau sebaliknya harus menutup usaha mereka. Meskipun banyak UKM yang terus bertambah, namun masih banyak dari mereka belum bisa menerapkan ilmu akuntansi atau bisa dikatakan "buta" akuntansi dalam usaha mereka terutama usaha yang masih berskala kecil. Maka dari itu, akuntansi sangatlah berperan besar dalam berjalannya UKM.

Selain pembukuan yang tepat, UKM juga perlu strategi yang tepat untuk mensukseskan usahanya. Strategi pemasaran merupakan komponen yang sangat penting dalam memulai suatu usaha. Jika tidak menggunakan strategi dalam usaha, maka semua kelangsungan usaha akan menjadi tidak beraturan dan dapat menyebabkan kerugian yang besar.

Akuntansi terdiri dari berbagai bidang, mulai dari bidang keuangan, pemeriksaan (audit), biaya, hingga manajemen. Manajemen sendiri merupakan salah satu komponen penting dalam menjalankan suatu usaha. Akuntansi manajemen merupakan salah satu komponen yang penting dalam suatu organisasi serta membantu organisasi dalam me- 
mecahkan masalah-masalah khusus yang terjadi di dalam organisasi (Kholmi, 2019). Akuntansi manajemen merupakan pemberi informasi dalam suatu perusahaan, maka dari itu banyak dari perusahaan menggunakan Five Porter Analysis sebagai informasi perkembangan usaha.

Five Porters Analysis adalah suatu model analisis yang dikembangkan oleh Michael Porter pada tahun 1980. Model analisis merupakan analisis yang memiliki pengaruh yang besar serta kontribusi terhadap teori yang berupa daya saing dan keuntungan kompetitif. (Widyasari, 2014).

UKM saat ini menjadi salah satu kegiatan perdagangan yang sangat diminati oleh masyarakat saat ini. Mereka dapat menjalankan usaha mereka baik dalam media online seperti media sosial dan aplikasi maupun offline seperti mempromosikan produk mereka secara langsung kepada pembeli. Namun, masih banyak dari mereka tidak memiliki strategi yang efektif dalam menjalankan usaha mereka. Mereka tidak dapat memprediksi apakah usaha mereka akan terus diminati oleh para pembeli dan apakah mereka bisa menghasilkan suatu produk dengan mengeluarkan biaya yang lebih rendah. Five Porters inilah yang akan memberikan informasi kepada pihak manajemen apa yang harus dilakukan agar usaha mereka tetap berjalan dan dapat mengurangi biaya-biaya yang tidak diperlukan.

Melihat permasalahan ini, maka penulis tertarik untuk melakukan penerapan Five Porters Analysis sebagai penunjang keefektifan kelangsungan UKM yang akan diterapkan ke salah satu UKM yaitu UD Rey Collection.

Tujuan dibuatnya penulisan ini adalah mengetahui besarnya ukuran keefektifan kelangsungan usaha pelaku UKM serta strategi usaha yang dapat diterapkan untuk memperkuat jangka berjalannya usaha dagang Rey Collection.

UKM didefinisikan oleh Peraturan Pemerintah No:8 Tahun 2008 sebagai suatu usaha kecil dan menegah sebagai kegiatan bisnis independen yang dilakukan oleh perorangan atau badan usaha yang buka merupakan anak perushaan atau cabang lain dari perusahaan atau dikendalikan atau menjadi bagian baik langsung maupun tidak langsung dari unit usaha menengah atau perusahaan besar (Nasip \& Sudarmaji, 2017). Menurut Kristiyanti (2015), UKM adalah kegiatan ekonomi yang dilakukan oleh individu atau suatu badan yang memiliki tujuan untuk memproduksi barang atau jasa untuk dijual dan memiliki omset penjualan kurang dari 1 miliar rupiah. Peran UKM itu sendiri adalah 
dapat mengurangi pengangguran dan kemiskinan sehingga menambah lapangan pekerjaan (Munizu, 2013).

Five Porters Analysis (Lima Analisa Porter) adalah sebuah kerangka kerja ntuk menganalisi tingkat persaingan dalam suatu industri dan strategi pengembangan bisnis dengan mempengaruhi atau mengubah kekuatan tersebut agar dapat memberikan situasi yang menguntungkan bagi perusahaan (Chandra, \&, 2016). Analisis ini dipublikasikan oleh Michael E Porter, seorang professor dari Havard Bussiness School. Persaingan antar perusahaan yang sudah ada sangat ketat, pesaing-pesaing baru bias masuk ke industry dengan relative mudah, dan baik pemasok maupun konsumen dapat memiliki daya tawar yang sangat besar (Rahma \& Pradhanawati, 2018).

Five Porter Analysis digunakan di bidang industri dan dapat diterapkan ke segala macam industri namun masih di dalam bidang sejenis. Bidang yang dimaksud adalah bisnis atau usaha yang menawarkan produk/jasa yang sejenis. Analisis ini berguna untuk memahami dan mengetahui posisi bisnis yang telah diterapkan sehingga dapat mengetahui strategi yang dapat digunakan untuk memperluas uasaha atau mengembangkan bisnisnya.

Isi dari Five Porter Analysis adalah antara lain:

Ancaman pendatang baru, Analisis ini menentukan seberapa mampukah usaha baru yang sejenis dapat bersaing dengan perusahaan lain. Ancaman ini akan muncul apabila perusahaan hanya menggunakan modal yang seadannya, tidak memiliki hak paten karena hak paten sangat bermanfaat untuk mengetahui keaslian dan hanya satu-satunya perusahaan yang memiliki produk yang berbeda dari perusahaan lain. Selain itu loyalitas pelanggan terhadap perusahaan semakin rendah karena pendatang baru yang lebih berkompeten dan memliki kualitas yang baik.

Kekuatan Pemasok, Daya pemasok mempengaruhi intesitas persaingan dalam industri khususnya pada saat pemasok dalam jumlah besar atau pada saat hanya ada sedikit pemasok atau bahan mentah pengganti yang bagus atau biaya bahan lain sangat tinggi (David, 2011). Jika pemasok memiliki daya tawar yang kuat, maka pemasok bisa menjual bahan mentah lebih tinggi atau lebih rendah. Daya tawar ini akan mempengaruhi hasil produk perusahaan sehingga perusahaan bisa menjual produk mereka lebih murah dan dapat mendatangkan para pembeli. Pemasok memiliki daya ta- 
war yang kuat (tinggi) jika ada sedikit pemasok tapi banyak pembeli, pemasok memiliki sumber daya yang langka, dan biaya bahan baku yang sangat tinggi.

Kekuatan Pembeli, Pembeli sangat mempengaruhi keberhasilan barang dan/atau jasa yang dihasilkan perusahaan. Pembeli berperan sebagai penentu perusahaan dalam menjual barang dan/atau jasanya lebih murah atau kualitas yang lebih tinggi. Semakin rendah kualitas produk perusahaan, semakin murah barang yang dijual, namun sebaliknya jika kualitas lebih tinggi, maka harganya lebih mahal dan kekuatan pembeli menjadi menurun. Ketika konsumen berkonsentrasi atau bebrbelanja dalam jumlah yang bersar, daya tawar mereka menunjukkan kekuatan yang besar sehingga dapat mempengaruhi persaingan dalam industri (David, 2011).

Ancaman Produk Pengganti, ancaman produk dapat muncul kaena disebabkan oleh factor-faktor yaitu harga relatif dalam kinerja barang pengganti, biaya pengalihan ke produk lain dan pembeli relatif mengganti produk (Refiasari, et. al, 2019). Sebagai contoh beralihnya penggunaan pertalite dari pertamax karena harganya yang lebih murah sehingga permintaan pertamax menjadi berkurang.

Persaingan di Antara Kompetitior yang Ada, Menurut David (2011), factor persaingan antar pesaing yang sama menjadi sentral kekuatan persaingan. Semakin tinggi tingkat persaingan, maka profitabilitas industry semakin tinggi ataupun bisa menurun (Refiasari, et. al, 2019). Analisis ini menjadi penentu utama seberapa kompetetif dan menguntungkan sebuah perusahaan. Namun, kekuatan ini bisa menurun jika perusahaan memiliki banyak pesaing, produk yang tidak bervariasi sehingga dengan mudah pembeli mencari barang pengganti, dan peran pembeli juga sangat berpengaruh karena sebuah loyalitas pelanggan mampu meningkatkan kekuatan analisis ini.

Manfaat dilakukannya Analisis Porter ini adalah perusahaan dapat mengetahui posisi mereka apakah mereka berada di dalam posisi sulit atau sedang berada di posisi puncak. Dengan memanfaatkan lima model kekuatan atau five forces sebagai dasar, disini kita dapat memahami tindakan yang diperlukan, seperti implementasi, proses lainnya dan teknik yang dapat memberikan kontirbusi yang menciptakan keunggulan kompetitif organisasi (Riky \& Ronny, 2014).

Analisis ini bisa membantu dalam rancangan analisis SWOT karena Five Porters Analysis memberikan gambaran yang kuat bagaimana posisi perusahaan di dalam suatu industri baik itu persaingan, pangsa pasar serta peran pembeli. 


\section{METODE PENELITIAN}

Subjek dalam penelitian ini adalah salah satu UKM yaitu UD Rey Collection dengan Fitry Hutagalung sebagai pemilik usaha. UKM ini beroperasi secara online melalui media sosial dan e-commerce. UD Rey Collection merupakan usaha yang bergerak di bidang fashion seperti pakaian anak-anak dan pakaian dewasa.

Metode yang digunakan untuk penulisan ini adalah menggunakan metode studi literatur dan wawancara dengan salah satu pelaku usaha UD Rey Collection. Studi literatur adalah melakukan pencarian informasi dari berbagai sumber tertulis yang berkaitan dengan permasalahan yang ingin dibahas. Sumber tersebut akan menjadi informasi yang memperkuat kajian dalam penelitian ini. Wawancara dilakukan untuk mengetahui permasalahan riil yang dibahas di penelitian ini sehingga penulis dapat mentukan solusi yang tepat sehubungan dengan permasalahan yang dibahas di penulisan ini.

Pertanyaan yang diajukan untuk pelaku usaha UD Rey Collection adalah sebagai berikut:

Tabel 1. Pertanyaan wawancara

\begin{tabular}{|l|l|}
\hline \multicolumn{1}{|c|}{ Acuan } & \multicolumn{1}{c|}{ Pertanyaan } \\
\hline Terbentuknya usaha & $\begin{array}{l}\text { 1. Sejak tahun berapa anda menjalankan bisnis anda? } \\
\text { 2. Berapa modal anda saat anda membangun usaha anda? }\end{array}$ \\
\hline Biaya usaha & $\begin{array}{l}\text { 3. Apakah sebelumnya merencanakan strategi sebelum resmi menjalankan usaha anda? } \\
\text { 1. Berapakah biaya operasional per bulannya? }\end{array}$ \\
Pendapatan usaha & $\begin{array}{l}\text { 2. Bagaimana anda mencari pemasok anda? } \\
\text { 1. Berapa penghasilan anda per bulan? }\end{array}$ \\
Pesaing & $\begin{array}{l}\text { 2. Apakah anda mengalami peningkatan atau penurunan pendapatan anda dalam } 6 \text { bulan terakhir? } \\
\text { Kendala usaha }\end{array}$ \\
\hline
\end{tabular}

\section{HASIL DAN PEMBAHASAN}

UD Rey Collection adalah usaha dagang yang bergerak di bidang fashion. Rey Collection memulai usahanya sejak tahun 2014. Rey Collection menjual pakaian baik pakaian anak, maupun dewasa. Bisnis ini juga menjual berbagai produk seperti pakaian muslim, selimut, seprai, dan alat tumah tangga sebagai penambah variasi produk di dalam bisnisnya. Bisnis ini dijalankan oleh Fitry Hutgalung dan awal bisnis ini berjalan dengan modal Rp. 300.000. Dalam memulai bisnisnya, Fitry awalnya mempromosikan produknya kepada teman-teman kantornya. Fitry masih menerapkan promosinya dari mulut ke mulut, ia mempromosikan produknya dari tetangganya lalu ke teman-teman 
dari sekolah anak-anaknya. Namun seiring berjalannya waktu Fitry menggunakan media sosial untuk memperluas produknya.

Untuk penghasilannya, Fitry bisa meraup keuntungan bersih sebesar Rp. 3.000.000 dilihat dari pembukuannya yang sederhana. Jiki dilihat, Fitry tidak mengeathui sistem perhitungan akuntansi dengan baik karena modalnya tiap bulan bisa mengalami kenaikan secara signifikan.

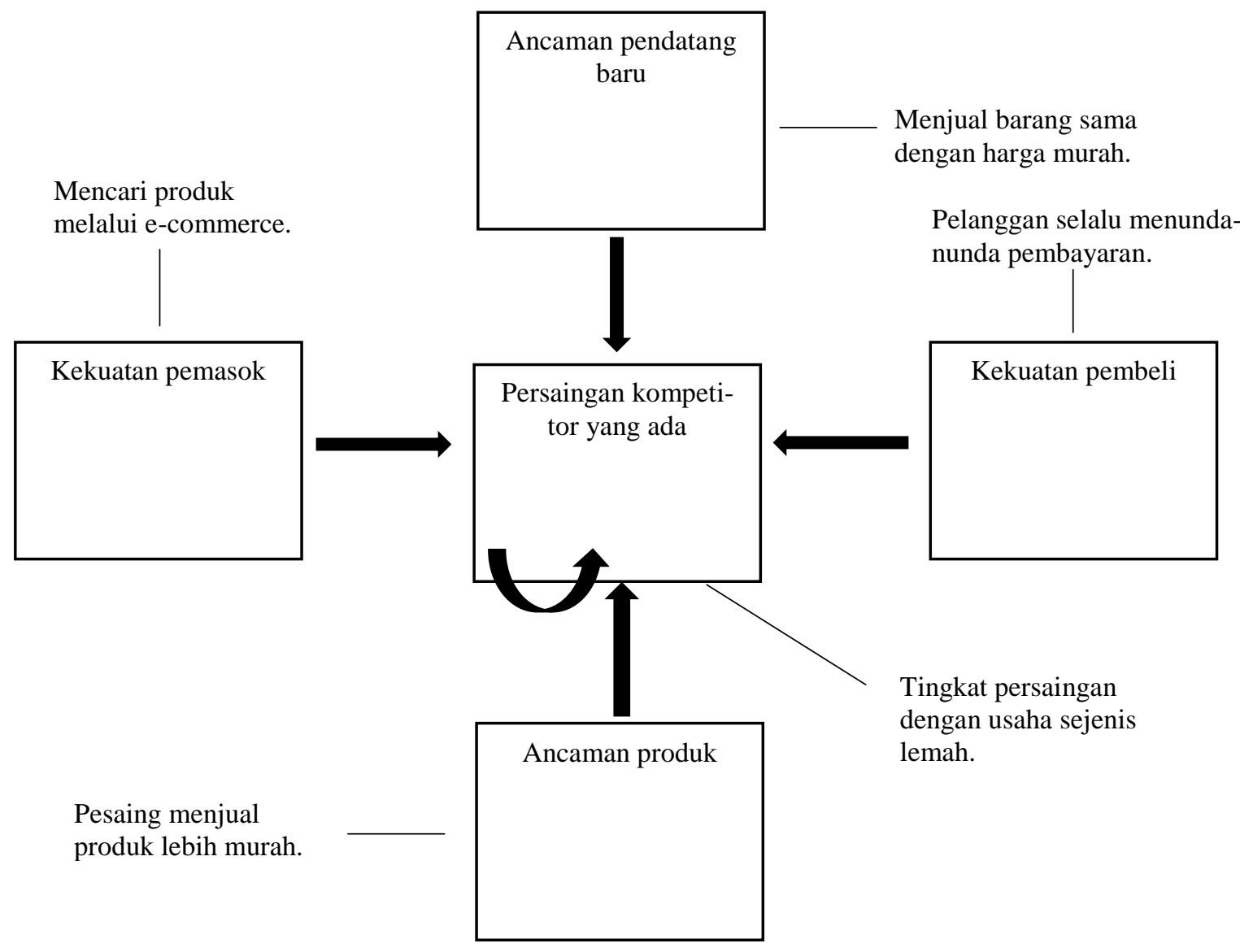

Gambar 1: Model Five Porter Analysis UD Rey Collection Sumber: Michael Porter (1980), analisis di olah

Ancaman Pendatang Baru, Ancaman yang dialami oleh UD Rey Collection adalah adanya usaha dagang lain yang menjual produk yang sama namun menjual dengan harga yang lebih murah. Fitry juga mengkhawatirkan pelanggan setia UD Rey Collection akan beralih ke usaha bisnis yang menjual produk lebih murah. Dilihat dari kondisi ini, UD Rey Collection belum bisa menetapkan pelanggan dan kurangya strategi dalam mempertahankan pelanggan. Selain itu, modal yang dimiliki UD Rey Collection yang 
tidak menentukan (kadang memiliki modal besar, kadang kecil) membuat penetapan harga produk yang dijual selalu mengalami perubahan.

Kekuatan Pemasok, Untuk produk yang dijual, Fitry mengambil barang dari $e$ commerce. Ia mencari produk yang memiliki harga murah lalu menjual kembali produk tersebut kepada pelanggan dengan menaikan harga dengan tujuan memperoleh keuntungan, sehingga UD Rey berjualan secara re-seller (menjual kembali). Daya pemasok yang dimiliki oleh Rey Collection masih sangat rendah karena barang yang dijual terdapat di e-commerce sehingga pelanggan lebih memilih membeli langsung di $e$ commerce langsung daripada membeli di Rey Collection. Dilihat dari kondisi ini, Rey Collection harus mencari pemasok lain yang memiliki sumber daya langka dan belum pernah dijual di tempat lain selain e-commerce.

Kekuatan Pembeli, Menurut Fitry, Rey Collection memiliki cukup banyak pelanggan mulai dari pelanggan daerahnya hingga pelanggan dari luar daerah yang didapat dari promosi melalui media sosial dan juga chat Whatsapp. Menurutnya, setiap bulan pasti ada pelanggan baru ataupun pelanggan yang pergi karena tidak ada kepastian juga pelanggan tersebut membeli produk dagangannya kembali. Penurunan kekuatan pembelinya adalah pada saat ingin mengirimkan pesanan ke luar daerah pembeli terlambat dalam melakukan pembayaran produk karena berbagai alasan, salah satunya adalah karena belum menerima gaji. Dalam hal ini, Rey Collection memiliki kebijakan pembayaran yang lemah karena dilihat dari pelanggan yang seenaknya menunda pembayaran produk bahkan sampai tidak jadi membeli barangnya sehingga mempengaruhi modal yang terbuang sia-sia.

Ancaman Produk, Ancaman produk menurut Fitry adalah adanya barang dari usaha dagang lain yang menawarkan harga lebih murah dengan bahan yang berkualitas tinggi. Hal ini dikarenakan Fitry hanya menjalankan usaha sebagai re-seller sehingga peluang untuk memperoleh barang/produk yang lebih bagus dari usaha dagang lain kecil. Hal ini dikarenakan modal yang tidak cukup untuk membuat produknya sendiri.

Persaingan Kompetitor yang Ada, Dalam persaingan dengan usaha lain, UD Rey Collection masih belum bisa meningkatkan usahanya terlihat dari analisa diatas. Hal ini dikarenakan kekuatan masing-masing Five Porter Analysis masih lemah, sehingga Rey Collection membutuhkan strategi yang matang agar dapat terus menjalankan usahanya dalam jangka waktu yang panjang. Karena sudah mengetahui seberapa besar kekuatan 
UD Rey Collection menggunakan Five Porter Analysis, maka diperlukan strategi usaha di masing-masing Analisa Porter agar memperoleh solusi dalam menjalankan usaha dagang yang efektif.

Dari analisis yang sudah dibuat dari infomasi yang disampaikan oleh pemilik usaha, dapat dilihat bahwa usaha dagang Rey Collection belum bisa mencapai efektifitas kelangsungan usaha dilihat dari penerapan Five Porter Analysis. Untuk mengatasi permasalahan ini, UD Rey Collection memerlukan strategi untuk masingmasing analisa yang sudah di buat.

Dalam mengatasi permasalahan tersebut, strategi yang dapat dilakukan adalah dengan memberikan promo atau potongan diskon kepada pelanggan agar pelanggan tersebut semakin tertarik dengan produk-produk yang ditawarkan oleh Fitry. Selain itu, pelaku usaha dapat melakukan pencarian pemasok yang memiliki nilai sumber daya yang bernilai langka sehingga mengurangi ancaman pendatang baru juga. Strategi yang disarankan untuk mengatasi pembayaran produk oleh pembeli adalah dengan cara memperkuat kebijakan toko, seperti membayar setengah harga (DP) terlebih dahulu kepada pelanggan agar pelaku usaha juga masih bisa menutup modal awal. Usahakan pemilik memiliki target pembeli dan juga mempromosikan barangnya lebih prioritaskan ke pembeli menengah kebawah.

\section{SIMPULAN}

UKM merupakan suatu kegiatan usaha yang dapat menggerakan pendapatan negara. UKM kini semakin diminati oleh para masyarakat dalam memperoleh keuntungan, namun UKM harus memiliki strategi yang tepat untuk memajukan UKM tersebut. Five Porter Analysis adalah analisis yang terdiri dari lima anilisis yang dapat mengetahui tingkat daya tarik pasar dalam suatu usaha. Analisis ini dapat digunakan di berbagai macam usaha baik UKM sampai perusahaan besar. Five Porter dapat mengetahui apakah suatu usaha sudah mencapai keefektifan serta mengetahui strategi yang bisa diterapkan agar dapat meningkatkan keefektifan dan pengembangan suatu kelangsungan usaha.

Berdasarkan wawancara yang telah dilakukan, hasil analisis menggunakan Five Porter Analysis adalah sebagai berikut: 
Ancaman pendatang baru merupakan nilai yang kuat bagi Fitry, hal ini dikarenakan banyak pesaingnya yang menjual produk yang sama dengannya namun dengan harga murah. Semakin tinggi nilai ancaman, maka semakin lemah nilai keefektifan kelangsungan usaha yang dijalankan Fitry. Kekuatan pemasok Fitry menunjukkan kelemahan, hal ini dikarenakan ia mendapatkan produk dijual dari tempat yang diketahui oleh banyak orang yaitu e-commerce. Kekuatan pemasok akan memiliki hasil yang baik penjual dapat menemukan pemasok yang memiliki sumber daya yang langka. Strategi yang dapat dilakukan oleh Fitry adalah dengan melakukan pencarian pemasok yang memiliki nilai sumber daya yang bernilai langka, hal ini juga akan berdampak pada pengurangan nilai ancaman pendatang baru.

Dalam kekuatan pembeli, Fitry lemah dalam menetapkan masyarakat menjadi pelanggan tetapnya serta lemahnya kebijakan dalam melakukan pembayaran secara online karena pelanggan yang seenaknya menunda-nunda pembayaran produk. Dalam mengatasi hal ini, strategi yang disarankan adalah dengan cara memperkuat kebijakan toko, seperti membayar setengah harga (DP) terlebih dahulu kepada pelanggan agar pelaku usaha juga masih bisa menutup modal awal. Ancaman produk dalam usaha Fitry juga menunjukkan kelemahan yaitu kualitas barangnya lebih rendah jika dibandingkan dengan pesaingnya. Strategi yang dapat dilakukan adalah mencari pemasok yang memiliki sumber daya langka.

Persaingan UD Rey Collection dengan competitor yang ada sangat lemah. Hal yang dapat dilakukan adalah dengan cara memiliki target dalam melakukan pemasaran. Target yang dapat dicapai untuk memunculkan pelanggan adalah dengan cara seperti mempromosikan produk yang diperuntukan untuk pelanggan kelas menengah kebawah.

Berdasarkan analisis yang sudah dilakukan, maka UD Rey Collection belum bisa dikatakan sebagai suatu usaha yang efektif dalam kelangsungannya. Hal ini dikarenakan masih banyak kekurangan dari setiap komponen-komponen Five Porter. Dengan diberlakukannya Five Porter Analysis, maka dengan mudah menemukan strategi yang tepat untuk setiap permasalahan yang ada.

\section{DAFTAR PUSTAKA}

Amiruddin, A. (2018). Pemberdayaan usaha kecil menengah (UKM) Binaan Dinas Perdagangan Kota Surabaya dalam Upaya Meningkatkan Kesejahteraan. (Doctoral Dissertation, Universitas Airlangga). 
David, F.R. (2011). Strategic Management, Concept and Cases, $13^{\text {th }}$ Edition. Upper Sadle River, NJ: Pearson Prentice Hall.

Kristiyanti, M. (2012). Peran Strategis Usaha Kecil Menengah (UKM) dalam Pembangunan Nasional. Majalah Ilmiah Informatika, 3(1), 63-89.

Martin, R., \& Hutagaol, N. (2012). Penerapan Akuntansi Pada Usaha Kecil Menengah. Jurnal Ilmiah Mahasiswa Akuntansi, 1(2).

Munizu, M. (2013). Strategi Peningkatan Kinerja dan Peran Usaha Kecil dan Menengah (Ukm) Pengolah Produk Berbasis Pangan. Journal of Management and Business, 12(1).

Nasip, I., \& Sudarmaji, E. (2017). Model Bisnis Kanvas: Alat untuk Mengidentifikasi Peluang Bisnis Baru bagi Pengusaha UKM Indonesia. In 1st National Conference on Business and Entrepreneurship.

Prananda, A. A., \& Datu, C. (2016). Peranan Sistem Informasi Akuntansi Manajemen Dalam Pegambilan Keputusan Investasi Asset Tetap Pada PT. Etmieco Sarana Laut Bitung. Jurnal EMBA: Jurnal Riset Ekonomi, Manajemen, Bisnis dan Akuntansi, 4(1).

Samantha, D. (2015). Analisis Strategi Bersaing pada Perusahaan Kotak Karton Gelombang Menggunakan Porter's Five Forces Analysis. Agora, 3(1), 686-690.

Rahma, A. N., \& Pradhanawati, A. (2018). Strategi Bersaing Produk UKM Lunpia dengan Menggunakan Analisis Five Forces Porter dan SWOT (Kasus pada UKM Lunpia Kings Semarang). Jurnal Ilmu Administrasi Bisnis, 7(2), 171-185.

Resalawati, A. (2011). Pengaruh Perkembangan Usaha Kecil Menengah Terhadap Pertumbuhan Ekonomi pada Sektor UKM di Indonesia.

Refiasari, D., Tristiyanto, T., \& Hijriani, A. (2019). Analisis Lima Kekuatan Porter pada Marketplace Pakan Ternak dan Produk Hasil Ternak (Studi Kasus: ePakan).

Riky, A. (2014). Porter Five Forces Model Pada PT. RUCI GAS. Agora, 2(2), 12851296.

Widyasari, D. (2014). Analisis Industri Alas Kaki di DKI Jakarta Tahun 2014 Dengan Model 'Porter's Five Forces'. Jurnal Ekonomika dan Manajemen, 3(2). 